\title{
The Analysis of Education Based on Ethnopedagogy in Forming Characters of 4th Grade Students in SDN 115 Pekanbaru
}

\author{
Tity Hastuti, Zaka Hadikusuma Ramadan \\ Universitas Islam Riau, Indonesia \\ tityhastuti@edu.uir.ac.id
}

\section{Abstract}

This research aims to; 1) describe ethnopedagogy learning in SDN115 Pekanbaru; 2) describe the formation of character in SDN 115 Pekanbaru; 3) describe what characters are formed for students in SDN 115 Pekanbaru; and 4) describe the factors that inhibit the implementation of character building through ethnopedagogy in SDN 115 Pekanbaru. This research uses a qualitative approach. The method used in this research is naturalistic inquiry. The sample of this research consisted of 1 Headmaster and 3 teachers from class IV. The location of research study was conducted in SDN 115 Pekanbaru. Data collection techniques in this research are; 1) interview; 2) observation; and 3) documentation. Data analysis of the research results used Miles and Huberman model, namely, data reduction, data display, drawing conclusion. Ethnopedagogy in SDN 115 is carried out with many programs, starting with the curriculum, namely the existence of Arabic Malay subject matter, and the existence of the obligatory study for 15 minutes before class time and the existence of Imtaq activities on every Friday. In addition, the latest program is the subject of Riau Malay Culture (BMR) which is an instruction from the Mayor of Pekanbaru as a means of preserving Riau's Malay culture to students. The process of habituation such as smiles and greetings is a routine activity every morning for teachers waiting in front of the gate to welcome students. Saying greetings when you meet is something that has been entrenched in SDN 115 Pekanbaru. In addition there are some words such as pointing Malay teaching that is posted on the school wall, which is essentially for students to see, to read and to remember. The characters developed in ethnopedagogy-based learning are religious, honest, diligent, disciplined, and caring/responsible. Related to the implementation and obstacles encountered and the solutions pursued by SDN 115 Pekanbaru in the implementation of ethnopedagogy. As for the obstacles including, accustoming students to love the environment, uniting the perspective and the purpose of classroom action research, students, and parents, disciplining students to arrive on time, lack of teaching materials in the form of BMR material. The solution sought by SDN 115 Pekanbaru is to keep trying to get used to, give examples, give advice, and provide guidance.

Keywords

ethnopedagogy, character, SDN

115 Pekanbaru

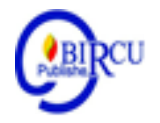

\section{Introduction}

Character has the same essence and meaning as behavior, morals or moral education. The aim is to shape the child's personality, so that he becomes a good person, if in the community he becomes a good citizen, and if in the life of the state he becomes a good citizen. Character building is done through positive arrangements at home, school and community. Therefore, 
schools as formal institutions must include character education through all subject matter in schools that are integrated with the school curriculum. It aims to realize a quality and cultured Indonesian nation, not only intelligent and faithful, but also hearted, feeling, and ethical. In addition, by educating children in the field of values starting from an early age, it is continuous and synergistic between family, school, and community education, because actually informal education that is instilled by parents in the family and community is more oriented towards values religious values and behavior of children. According to Sembiring (2019) character is the attitude and way of thinking, behaving and interacting as a characteristic of an individual in life, acting and working together, both within the scope of the family, community and nation. Character will be a part of one's identity so that it can be a good identity or personality.

SDN 115 Pekanbaru is a school that implements Curriculum 2013. Where 2013 curriculum is a curriculum that emphasizes character education. Besides that, in SDN 115 Pekanbaru, the subject has also applied Malay Arabic subjects and Riau Malay Culture which are subject to local wisdom in Riau (Ethnopedagogy). Based on preliminary data that researchers got from the fourth grade teachers of SDN 115 Pekanbaru, explained that ethnopegogical activities have been applied, for example, when every meeting with teachers or parents is required to kiss hands, say hello. This is done continuously until accustomed to students and certainly become good characters for students. Based on that the researcher wants to explore how the implementation of character formation in SDN 115 Pekanbaru through ethnopedagogy in learning. Of course as education practitioners, in this case lecturers, consider how important character education is applied early in learning in schools. Seeing the phenomena that occur at this time is certainly a special concern how to improve student character so that it cannot be separated from the identity of the Indonesian people.

As if the Indonesian people lost their true identity. The noble values of the nation's culture which have always been owned and as forming the identity of the nation's children whose character is now starting to wear off by eastern cultures that are not in accordance with the culture of the Indonesian Nation. Foreign culture that is thick with glamor is preferred by teenagers today and in the end the domestic culture must be defeated. To overcome these problems in schools in learning to integrate local wisdom (ethnopendagogy). The importance of local wisdom in learning marked by globalization has forced us to obey its demands, so that the culture in the world becomes uniform, materialism, westernization, westernization, and even Americanization, in thinking, behaving and material patterns.

\section{Research Methods}

This research uses a qualitative approach. In this research, researchers tried to explore and develop an understanding of character formation through ethnopedagogy in learning at SDN 115 Pekanbaru. The method used in this research is naturalistic inquiry. Hatch (2002: 26) refers to Lincoln and Guba (1985) as initiating naturalistic inquiry, Hatch defines naturalistic inquiry as a direct method to get activities that occur naturally in the field. The research design can be seen in the image below. 


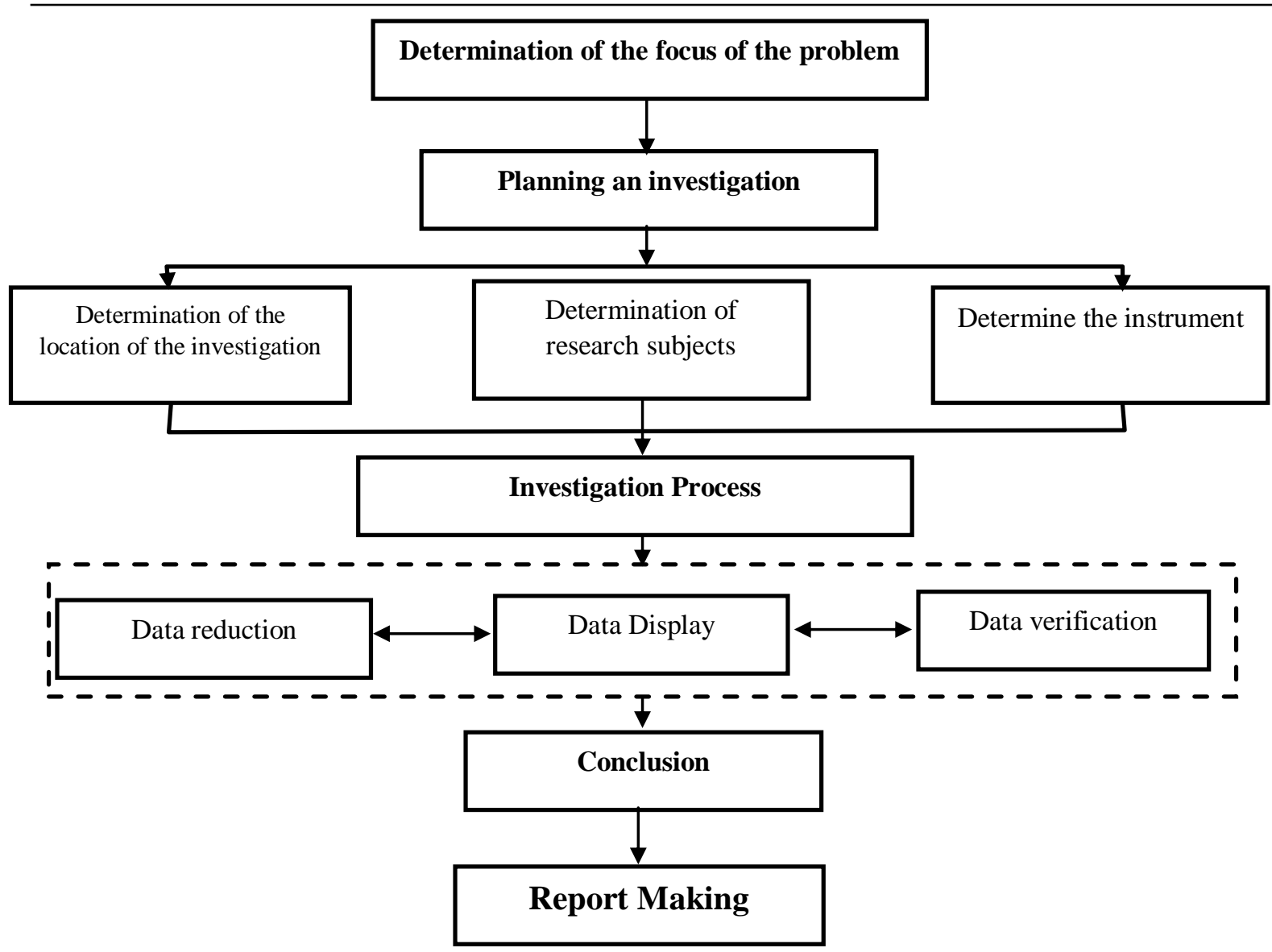

Figure 1. Research Flow Diagram

The location of this study was conducted in SDN 115 Pekanbaru which is located on Jalan Kaharuddin Nasution, Simpang Tiga Village, Marpoyan Damai Sub-district, Pekanbaru City, Riau Province. The selection of this school is based on the fact that this school is one of the pilot schools in the implementation of the 2013 curriculum. In analyzing the results of this study the researchers used the Miles and Huberman models. Analysis of the data in this study continues. Sugiyono (2014) described the analysis of research data using the Miles and Huberman models, namely, data reduction, data display, conclusion drawing, as shown below:

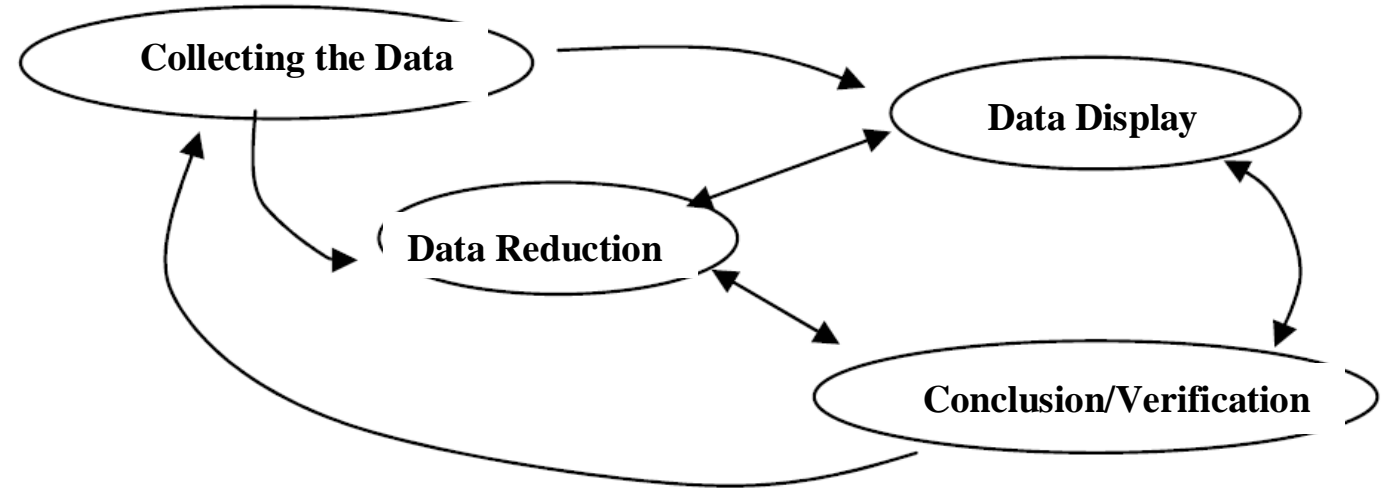

Figure 2. The Illustration of Miles and Huberman's Data Analysis Model 


\section{Discussion}

\subsection{Research Result}

This research was carried out in SDN 115 Pekanbaru. Researchers used interview techniques to obtain data on the process of implementing character education in SDN 115 Pekanbaru from the viewpoint of educators and education personnel. Informants in the interview process included: the principal, and representatives of the fourth grade guardians as teachers appointed by the school.

Based on the results of interviews and documentation shows that the process of implementing character education in SDN 115 Pekanbaru is carried out starting from the beginning when students enter the school gate. SDN 115 Pekanbaru seems to have a high commitment in instilling and developing character values. This can be seen from the vision and mission of the school, good school facilities, and the condition of the school which is quite neat, clean, and comfortable. Facilities such as classrooms and other infrastructure are also quite adequate. This certainly can support in the process of implementing the value of character education in schools. The following is an explanation of the process of implementing character values in SDN 115 Pekanbaru obtained from interviews and documentation.

\section{a. Ethnopedagogy Based Learning}

Ethnopedagogy is culture-based learning. Especially in Riau Province which is culturally Malay, then the learning process in schools should apply habituation that is oriented towards Malay culture. This is what will be explained in this sub.

SDN 115 Pekanbaru based on the results of the study obtained information that has carried out ethnopedagogy in the learning process. This can be seen from the structure of subject matter, the existence of Arabic Malay subjects and Riau Malay Culture (BMR). Ethnoedagogy has been applied in daily activities in its learning, for example on Friday students and teachers are required to wear Malay clothes.

One of the characteristics of Malay culture is the religion of Islam, so Islamic studies such as on Friday in SDN 115 Pekanbaru are implemented by Imtaq (Faith and Taqwa) by reciting together and occasionally inviting teacher (Ustadz) or religious leaders to fill in these activities. The activity is carried out for 30 minutes. Based on observations that have been made in SDN 115 Pekanbaru there are a number of routines related to ethnopedagogy learning as follows:

1) Ethnopedagogy Learning Routines

Monday - Thursday Recite the Qur'an is held independently in the classroom for 15 minutes before the learning process begins. Friday, is also different from other days. Today SDN 115 Pekanbaru carries out religious activities for those who are Muslim, this activity is named Imtaq (Faith and Taqwa). Like every day, the bell rings at 07:00 WIB. All students line up according to their respective classes, then after neat students stretch out their prayer rugs in Pekarang and sit on them.

Imtaq activities last for approximately 30 minutes. In this activity, the $\mathrm{MC}$ is a picket teacher, in which there is also an activity of religious lectures delivered by one of the religious teachers, there are also short-term murajaah activities in the Koran, and also nasyid. 


\section{2) Cultivation in Schools}

School culture or what is known by another term that is school culture in question are unwritten habits that have existed for a long time in this school. As for some school cultures in SDN 115 Pekanbaru based on observations and notes while in the field are as follows:

The call "Father and Mother" to the teacher, There are goals to be achieved from this culture. The call "Father and Mother" aims to create closeness between the teacher and students, so that students feel they make their teachers become "Father and Mother" or like parents at school. However, the call "Father and Mother" is not just a call, but is a responsibility for educators and education staff towards students in SDN 115 Pekanbaru. That is, the attitude shown is no longer just a teacher, but also as a parent at school.

Shaking hands with the teacher, in the morning when the bell has not rang one or sometimes more than one teacher stands barking near the school gate to greet students who come through the school gate. Every student who came to greet these teachers and even some of the students said greetings "Assalammualaikum" for those who are Muslim and "Morning bun / well ..." for those who are not Muslim. Figure 4.2 follows one of the pictures that shows the culture of shaking hands with the teacher in the morning when he comes every day.

This culture is also a culture that has existed for a long time. This includes positive activities, because it is considered as one of the ways students show respect, courtesy, courtesy, and friendliness to teachers or older people and teach to their younger siblings.

The role of the class leader, the culture of respecting the figure of the class president are also characteristic of SDN 115 Pekanbaru that attracts the attention of researchers. In SDN 115 Pekanbaru, the class leader plays the figure of a leader who is quite respected by his classmates. Not just leading the line, leading when reading the Koran, leading when saying greetings, collecting infaq money, raiding desk drawers that store trash, watching pickets, even cleaning trash cans by directing his friends. Like the results of interviews obtained from two students of class III and one of the following teachers.

In addition to the class leader, the responsibility for class cleanliness is also entrusted to the cleanliness section in each class. The class president works closely with the cleanliness section on the cleanliness of each class, certainly under the supervision of the homeroom teacher.

Picket at school hours, this school does not apply written rules for this one culture, but all classes apply these rules except classes I and II whose classes are used mutually. For classes III, IV, V, and VI, class pickets are done after the bell home sounds. That is, for students who get a picket turn for tomorrow, the picket is held today after the bell rings. However, some students picket back in the morning before the bell rings.

The responsibility of picket has even been given to class I and II students with different levels of supervision from the homeroom teacher. The lower the grade level, the higher the supervision provided by the homeroom teacher. Not only supervises students to be responsible for their class picket schedule, but the homeroom teacher as a teacher also teaches how to use cleaning tools such as brooms, trash shovels, and watering plants. In addition, the homeroom teacher also reminded him to wash his hands after carrying out the class picket.

In addition, the class leader also has an important role in the implementation of this class picket. In addition to the teacher, the class leader also supervises any of his friends who are picket and not picket, then gives a warning, if the warning is still ignored, then the 
class leader will report to the homeroom teacher. Regarding the implementation of class picket, the class president also works closely with the cleaning section.

Environmental advice when learning, culture provides advice on protecting the environment when students are involved in learning activities. The advice given is not even included in the demands of learning objectives. Simple advice like storing trash in a bag first if you haven't found a trash can yet, and throwing it away if you've found a trash can. As the results of the following interview, the researchers asked.

Environmental advice when marching in the morning, as has been explained before, activities provide direction, advice, or motivation every morning when all students line up in the field. Although not given every day, advice on protecting the environment is given occasionally in routine activities.

Picking up trash every time you break up, this activity is also one of the longstanding school cultures. This activity is still carried out by the school community even though the yard is clean, so this activity seems to require students to be more observant to see the garbage around them even though the trash is small. It appears students on Saturday after the break up pick up junior high school that is around them.

Based on the observations and observations of the field researchers, the activity of picking up trash after the line is dispersed in the morning routine before the students enter their classes is instructed by the picket teacher. This activity becomes an effective routine to reduce waste that may be hidden or not previously seen by picket students or school guards who also carry out cleaning activities.

\section{b. Character Building Through Ethnopedagogy}

Ethnopedagogy learning is actually learning that emphasizes cultural activities in learning. So in this ethnopedagogy-based learning there are also original Indonesian characters who have been around for a long time. With ethnopedagogy based learning, students are expected to be able to form characters that become original characters through the nation's culture. At the 115th Elementary School itself, ethnopedagogy-based learning has long been carried out. Based on information from the teacher through interview activities that with ethnopedagogy activities such as welcoming students at the front gate requires students to be disciplined and have a polite and polite character towards their teacher.

Based on the results of the answers from the teacher, of course, it can be concluded that habituation through ethnopedaogical activities greatly affects the formation of student character. Because these habits can be entrenched and in the end formed characters such as religious, responsibility, and discipline. It can be concluded in the ethnopedagogy learning that the characters develop are religious, honest, diligent, disciplined and caring as well as responsibility. In implementing ethnopedagogy learning, it turns out that if it is carried out through habituation, it can shape the character of the child. The character of children can be formed with simple things that can be done every day by students both at school and at home.

\section{c. Obstacles and Solutions Faced}

Ethnopedagogical implementation in this case is BMR according to the Headmaster and teacher is something very good. So that children do not forget the origins, do not forget the history of the region, its culture and of course can preserve it. So students are not uprooted from the roots of their own people.

In the course of implementation there are obstacles encountered. Mainly because students consist of several different tribes. This also makes it difficult for teachers to implement the 
BMR. The level of discipline is also still lacking due to parents who are still in the middle to lower category. Besides books and materials are also still very limited. So according to teachers and school principals, material books relating to BMR learning need to be developed. Solutions given by the school is by not discriminating between ethnic groups, closing the fence for students who are late but after that students will be allowed to enter the school with a note will be asked in advance why the child is late. No sanctions are given. Then overcome the limitations of teaching materials or of course material by utilizing the internet to search for materials related to BMR itself.

In addition to learning in the classroom, one of the entopedagogies implemented in SDN 115 Pekanbaru is by displaying advice that comes from Malay culture such as pointing at Malay and there is also Asmaul Husna on display on the wall of the school.

\subsection{Discussion}

The implementation of ethnopedagogy in SDN 115 Pekanbaru, which was presented in the results of the study, had been carried out in accordance with Malay culture, one of which was the existence of Arabic Malay and BMR subject matter which had only been carried out one year in each school. In addition, school activities related to ethnopedagogy are the custom of reciting to students which takes place 15 minutes before class time and specifically on Friday the Imtaq. The activity is part of the implementation of Malay cultural ethnopedagogy, one of the characteristics of Malay culture is the religion of Islam. In addition, Malay clothes are also required of all teachers and students every Friday. This is in line with Mariane (2014) explaining the definition of culture in the science of anthropology, namely, patterns of behavior and thinking of people who live in social groups learning, creating, and sharing.

Law No. 20 of 2003 concerning the National Education System contains the word school in the format of formal education with the levels of basic education, secondary education, and higher education (Law No. 20 of 2003 concerning the National Education System). This indicates that the school is an institution that organizes education to achieve educational goals. Thus, schools cannot stand without the elements that build them. The elements that build schools are Educators and Education Personnel (PTK), students, infrastructure, educational activities, values and culture that builds a school's identity (Sari, 2014).

Of the elements that build the school, there are similarities with the elements that build cultural existence, namely, the existence of humans (CAR and students) in study groups (levels) who create (generate ideas or think) and share (educational activities). The relationship created can be illustrated by the existence of culture in the concept of school, the existence of school elements in the concept of culture.

Ethnopedagogy in this case is the school culture is a set of norms, values and beliefs, habits and celebrations, symbols and stories or stories that shape the character of the school (Peterson and Deal, 1998). That is, school culture is shaped by the history or story of the school, the situation or condition of the school, and the people in it. Thus, school culture is not spontaneous and hereinafter referred to as culture, but if it has characterized a school then it can be called school culture. As stated by Dealing and Peterson in Hongboontri and Keawkhong (2014) that school culture is a tradition and ritual that has been built up from time to time by teachers, students, parents, and administrators who work together with agreements and achievement goals.

School culture is also divided into two types by Rosenholtz in Hongboontri (2014), namely, school culture that is routine or certain and not routine or uncertain. Based on these explanations, it can be further developed in its implementation, which is routine or certain even 
becomes part of the vision, mission, goals of the school, as well as being part of the school code of conduct, and not routine is a kind of habit that is built by the role of figures or influential people in school.

Thus, it is important to create or give birth to cultures that have positive value in order to create a quality academic climate. The description of the vision, mission, and goals of the school listed can be used as a basis for creating a positive culture in schools. Triatna (2014) interpreted the vision, mission, and goals of the school that is, the vision was interpreted as an optimistic but realistic dream about what kind of picture of our hopes for the school, a statement of preparation for the future, and a stated goal and give direction; mission is an effort that must be carried out by the organization so that what has been targeted at the vision can be achieved appropriately; school goals are intermediaries to achieve school vision gradually.

School culture as stated in different visions, missions, and goals in each school or educational institution if it is truly used as a reference by school members will produce a variety of graduate students, which is in accordance with the vision, mission, and goals of the school. Therefore, although school culture is built by the same components, there is no school culture that is exactly the same. This indicates the school culture contained in the vision, mission, and goals of the school gives influence to the graduates of a school. Research conducted by Slameto and Zubaidah found that school culture had a positive influence on the quality of education in the medium category (Slameto and Zubaidah, t.t.).

In addition, the role of the teacher in the school will also have an influence on the existence of school culture because this figure is the creator of that culture. As explained by Kholis et al (2014), that school culture is something that is very essential and is always related to all aspects of life in school, within the philosophy and ideology, values and norms of the school community. Kholis et al also emphasized that there is a school culture because it is influenced by leadership, teamwork, organizational characteristics, and developing administrative processes. Based on the concept of school culture offered by Kholis et al, there is an understanding that school culture is built by influential figures in schools both in structural and functional positions. In SDN 115 Pekanbaru, the figures that have an influence on the existence of school culture are the principal, teachers, education personnel, parents of students, and students. These figures are netted in the structural arrangement of the school organization. Thus, the leadership function is the most dominant of the existence of school culture.

The smallest organizational structure in a school is in the classroom, students are led by their respective class leaders. The class leader as a respected figure might be the forerunner of students' respect for their homeroom teacher as well as for other teachers (leaders of higher organizations). As in SDN 115 Pekanbaru, the class leader is quite influential as the leader of his friends. It is not uncommon for the class leader to replace the teacher's position as a picket supervisor, besides that the class leader is also responsible for managing waste in each class in collaboration with the cleaning section. In the learning activities, the class leader is given trust in several things, for example checking the trash in the drawer of his friend's desk or reprimanding his friend for throwing the trash out of the trash.

The teacher is also a figure who plays an important role, not only in the classroom as the homeroom teacher but also outside the classroom as a teacher for other students. The real effort that can be done by the teacher in the ethnopedagogy of students outside the classroom is to make themselves as models for students and for other teachers. Give examples without the impression of commanding students, namely more precisely by inviting. In this case, the teacher must bring up his personal competence so that students have a good perception and 
make him a figure who can be an example or role model. In the Law of the Republic of Indonesia Number 14 of 2005 Concerning Teachers and Lecturers Article 10 Paragraph (1), what is meant by the teacher's personal competence is a strong, noble, wise, and authoritative personality ability as an example of students (RI Law Number 14 Year) 2005 About Teachers and Lecturers).

The system that runs in schools as a form of culture that was created will be able to survive because of the leadership role of the principal. Thus, not only the teacher as a role model, the principal who is in the top position of leadership should also have personal competence. Based on the Minister of National Education Regulation No. 28 of 2010 concerning the Assignment of Teachers as Principals / Madrasas Chapter I Article 1 (5), the competencies of principals / principals are knowledge, attitudes and skills on the dimensions of personality, managerial, entrepreneurship, supervision, and competency dimensions social affairs (Permendiknas Number 28 Year 2010). In addition, ethnopedagogy in learning turns out that if it is carried out continuously and become a habituation program, it certainly can shape the character of students. Characters are formed through simple habituation activities that are continuously carried out so that they are entrenched and have an impact on the formation of student characters.

\section{Conclusion}

From the discussion above, it concluded that:

1. Ethnopedagogy in SDN 115 Pekanbaru is carried out with many programs, starting from the curriculum which is the subject of Arabic Malay subjects, as well as having the obligation to study for 15 minutes before class time and the existence of Imtaq activities on every Friday. In addition, the latest program is the subject of Riau Malay Culture (BMR) which is an instruction from the Mayor of Pekanbaru as a means of preserving Riau's Malay culture to students. The process of habituation such as $3 \mathrm{~S}$ (smiles, greetings and greetings) is a routine activity every morning for teachers waiting in front of the gate to welcome students. Saying greetings when you meet is something that has been entrenched in SDN 115 Pekanbaru. In addition there are some words such as pointing Malay teaching that is posted on the school wall, which is essentially for students to see, students read and students remember.

2. Characters developed in ethnopedagogy-based learning are religious, honest, diligent, disciplined, and care/responsibility

3. Related to the implementation and obstacles encountered and the solutions pursued by SDN 115 Pekanbaru in the effort to implement ethnopedagogy. As for the obstacles including, accustoming students to love the environment, uniting the perspective and goals of CAR, students, and parents, disciplining students to arrive on time, lack of teaching materials in the form of BMR material. The solution sought by the SDN 115 Pekanbaru is to keep trying to get used to, give examples, give advice, and provide guidance.

Based on the results of research conducted by researchers provide the following recommendations:

1. Ethnopedagogy is very important to be applied in elementary schools. So students are not uprooted from the roots of their own people. And culture-oriented learning implemented in schools is one way to realize the vision of Riau Province 2020 as a center of Malay culture.

2. The parents of students in SDN 115 Pekanbarus should be able to collaborate with the school both in particular in the implementation of ethnpedagogy, because these efforts are not enough just to rely on the school as an educational institution. Likewise in terms of 
being a role model at home and outside the home in environmental activities. Parents should also show friendly behavior and provide examples of good behavior in order to be an example for their children, and continue to learn to teach children.

\section{References}

Hatch, A. J. (2002). Doing Qualitative Research in Education Settings. New York: State University of New York Press, Albany

Hongboontri, C., \& Keawkhong, N. (2014). School Culture: Teachers' Beliefs, Behaviours, and Instructional Practices. Australian Journal of Teacher Education Volume 39| Issue 5 | Article 5. Page 66-88

Kholis, N., et al. (2014). Mutu Sekolah dan Budaya Partisipasi Stakeholders: Studi Fenomenologi di Sekolah Konfensional MIN Tegalasri Wlingi Blitar. Jurnal Pembangunan Pendidikan: Fondasi dan Aplikasi Volume 2, Nomor 2, 2014. Hal. 130142

Lincoln Y.S., dan Guba E.G. (1985). Naturalistic Inquiry. London: SAGE

Mariane, I. (2014). Kearifan Lokal Pengelolaan Huatan Adat. Jakarta: PT RajaGrafindo Persada

Peterson, D. K., \& Deal, E. T. (1998). How Leaders Influence the Culture of School. Journal of Educational Leadership Volume 56 Number 1 September 1998 Realizing a Positive School Climate Pages 28-30

Sembiring, A., S., et al. (2019). Character Formation Based on North Sumatra Local Wisdom through Orchestral Learning in Music Education Study Program, Universitas Negeri Medan. Budapest International Research and Critics Institute (BIRCI-Journal), 2 (4); 315-325.

Sari, P. I. (2014). Persepsi Guru Tentang Budaya Sekolah Pada SMA Negeri di Kabupaten Lima Puluh Kota. Jurnal Administrasi Pendidikan Volume 2 Nomor 1, Juni 2014 Halaman 315-831

Sugiyono. (2014). Metode Penelitian Pendidikan Pendekatan Kuantitatif, Kualitatif, dan R\&D. Bandung: Alfabeta

Triatna, C. (2014). Pengembangan Manajemen Sekolah. Bandung: Remaja Rosda Karya 